\title{
The Effects of Guar Meal on Production Performances in Broiler Chicken
}

\author{
Aurel ŞARA ${ }^{1) *}$, Mihai-Iacob BENȚEA ${ }^{1)}$ \\ 1) Department of Animal Nutrition, University of Agricultural Sciences and Veterinary Medicine, Cluj- \\ Napoca, 3-5 Manastur Street, 400372, Cluj-Napoca, Romania \\ *Corresponding author, e-mail: asara950@yahoo.com \\ Bulletin UASVM Animal Science and Biotechnologies 72(2) / 2015 \\ Print ISSN 1843-5262; Electronic ISSN 1843-536X \\ DOI:10.15835/buasvmcn-asb:11356
}

\begin{abstract}
Research carried out by the Chemical SRL Company in partnership with the University of Milan on broiler chicken, regarding the replacement of soybean meal with guar meal (Guar 60PF and Guar 70 PFR) highlighted a higher body mass for the groups that received Guar 70 PFR and Guar 60 PF, the control group showing smaller body mass values. Regarding the average daily gain, the higher values were recorded in the experimental groups, the highest value being recorded in Guar 70 PFR group, followed by the Guar 60 PF group, and the control group. The food conversion ratio was lower for the Guar 70 PFR and Guar 60 PF groups. Other authors reported that guar meal administered in low doses $(2.5 \%$ and $5 \%)$ in feeds had no negative effects on the growth performances of broiler chickens, whereas higher doses (7.5 and 10\%) negatively influenced both growth performances and broiler chickens' health. After partially replacing the soybean meal with guar meal in broiler chicken feeds, no negative effects on body mass evolution, weight gain, feed conversion and carcass quality in broiler chicken were reported.
\end{abstract}

Keywords: guar, broiler chicken, productive performances

\section{INTRODUCTION}

Guar (Cyamopsis tetragonoloba) is an annual pulse from the dry tropical regions of Asia. Guar 60PF and Guar 70PFR can be used in broiler chicken nutrition in lower doses, partially replacing the soybean meal in the structure of combined fodder.

The use of guar meal in broiler chicken nutrition. Research carried out by Chemical SRL Company in cooperation with the University of Milan on broiler chicken, regarding the replacement of soybean meal with 5\% guar meal (Guar 60PF and Guar 70 PFR) or 10\% (Guar 60 PFR) recorded higher body masses for the group that received 5\% Guar 70 PF (1966,38 g), followed by the group that received 5\% Guar 60 PF (1845,68 g), the control group having the lowest body mass values $(1827,37 \mathrm{~g})$. Higher values of average daily gain were recorded in both experimental groups, the 5\% Guar 70 PFR group showing a daily gain of $44,59 \mathrm{~g} /$ day, followed by the $5 \%$ Guar $60 \mathrm{PF}$ group (41,72 g/day) and the control group (41,34 g/day). The food conversion ratio was lower for the 5\% Guar 70 PFR group (1.68:1), followed by the $5 \%$ Guar $60 \mathrm{PF}$ group $(1,72: 1)$ and the control group (1,76:1). (tab. 1):

Similar results were also reported by Lee et al. (2003). They reported that guar meal, administered in doses of $2.5 \%$ and $5 \%$ in feeds, had no negative effects on the growth performances of broiler chickens, whereas higher doses (7.5 and 10\%) negatively influenced both growth performances and broiler chicken health. Gheisari et al. (2011), after replacing the soybean meal in broiler chicken feeds in doses of $3-18 \%$, in the 3 growth stages, reported an improvement of the growth performances and carcass parameters for the lower doses (3-9\%) and a decrease of the same parameters for doses of $12-18 \%$.

Mishra et al. (2013), after partially replacing the soybean meal with guar meal in broiler chicken feeds, reported that the gradual replacement $(2 \%$ in the $1^{\text {st }}$ phase and $5 \%$ in the $2^{\text {nd }}$ and $3^{\text {rd }}$ growth 
Tab.1. The effects of guar meal on production and consumption parameters in broiler chicken (Chemical SRL Milano)

\begin{tabular}{|c|c|c|c|c|c|}
\hline Issue & UM & Control & $\begin{array}{c}\text { Group } 1 \\
60 \mathrm{PF}(5 \%)\end{array}$ & $\begin{array}{c}\text { Group } 2 \\
70 \text { PFR }(5 \%)\end{array}$ & $\begin{array}{c}\text { Group } 3 \\
60 \text { PF (10\%) }\end{array}$ \\
\hline Body mass & $\mathrm{g}$ & $1827.37^{\mathrm{A}}$ & $1845.68^{\mathrm{A}}$ & $1966.38^{\mathrm{C}}$ & $1729.31^{\mathrm{B}}$ \\
\hline Weight gain & g/bird/day & $41.34^{\mathrm{Ba}}$ & $41.72^{\mathrm{Ba}}$ & $44.59^{\mathrm{A}}$ & $39.10^{\mathrm{Bb}}$ \\
\hline Feed consumption & g/bird/day & $75.36^{\mathrm{a}}$ & $75.34^{\mathrm{a}}$ & $77.31^{\mathrm{A}}$ & $72.87^{\mathrm{Bb}}$ \\
\hline $\begin{array}{l}\text { Feed conversion ratio } \\
\text { (FCR) }\end{array}$ & $\begin{array}{l}\text { kg of feed/ kg } \\
\text { gain }\end{array}$ & 1.76 & 1.72 & 1.68 & 1.81 \\
\hline
\end{tabular}

Tab.2. The effects of guar meal in different doses, on production and consumption parameters in broiler chicken (Kamran cited by Hussain et al., 2012)

\begin{tabular}{cccccc}
\hline issue & UM & $\begin{array}{c}\text { Control } \\
(0 \% \text { guar meal })\end{array}$ & $\begin{array}{c}\text { Group1 } \\
(5 \% \text { guar meal })\end{array}$ & $\begin{array}{c}\text { Group 2 } \\
(10 \% \text { guar meal })\end{array}$ & $\begin{array}{c}\text { Group 3 } \\
(15 \%\end{array}$ \\
\hline guar meal $)$
\end{tabular}

phases) had no negative effects on body mass evolution, weight gain, feed conversion and carcass quality in broiler chicken, also recording high production indices throughout the experimental period; in addition, carcass quality was not deprecated after replacing the soybean meal with guar meal.

Kamran cited by Hussain et al., (2012), after administering guar meal in doses of $5 \%, 10 \%$ and $15 \%$, reported a reduction of the weight gain proportional with the increase in the administered dose of guar, also positively correlated with an increase in the feed conversion ratio of the broiler chicken. The survival rate was also influenced by the different inclusion ratios, the group that received $5 \%$ guar meal showing the lowest survival rates compared to the other experimental groups and also to the control group; mortality rates rose with the increasing dose (being 6.66\% in the 15\% guar meal group) (Table 2).

\section{REFERENCES}

1. Gheisari AA, Shavakhi Zavareh M, Toghyani M, Bahadoran R, Toghyani M. (2011). Application of incremental program, an effective way to optimize dietary inclusion rate of guar meal in broiler chicks. Livestock Science, 140, (1-3): 117-123.

2. Hussain M, Rehman AU and Khalid MF. (2012). Feeding value of guar meal and the application of enzymes in improving nutritive value for broilers. World's Poultry Science Journal, 68: 253-268.

3. Lee JT, Bailey CA, Cartwright AL. (2003). Guar meal germ and hull fractions differently affect growth performance and intestinal viscosity of broiler chickens. Poultry Science, 82, (10): 1589-1595.

4. Mishra A, Sarkar SK, Subhasish R. and Haldar S. (2013). Effects of partial replacement of soybean meal with roasted guar korma and supplementation of mannanase on performance and carcass traits of commercial broiler chickens. Veterinary World, (6): 693-697.

5. http://www.chemicalsrl.com, The administration of Guar meal in broiler chickens: effects on growth performance, accessed march 2015. 